\title{
Ultrasound Microbubbles-mediated Microrna-505 Regulates Cervical Cancer Cell Growth via AKT2
}

\section{Leilei Xu ( $\sim$ LeileiXu3161@163.com )}

the First Hospital of Huai'an Affiliated to Nanjing Medical University https://orcid.org/0000-0001-79287881

\section{Qin Zhang}

the First Hospital of Huai'an Affiliated to Nanjing Medical University

\section{Changhua Li}

the First Hospital of Huai'an Affiliated to Nanjing Medical University

\section{Fu Hua}

the First Hospital of Huai'an Affiliated to Nanjing Medical University

Xiaoping Liu

the First Hospital of Huai'an Affiliated to Nanjing Medical University

\section{Research}

Keywords: Cervical cancer, Microbubbles, Ultrasound, microRNA-505, AKT2

Posted Date: August 19th, 2020

DOl: https://doi.org/10.21203/rs.3.rs-34897/v2

License: (c) (i) This work is licensed under a Creative Commons Attribution 4.0 International License.

Read Full License 
The authors have withdrawn this preprint from Research Square 